UDC 539.3

DOI: $10.32326 / 1814-9146-2019-81-2-240-248$

\title{
LOAD-BEARING CAPACITY ANALYSIS OF BUILDING PARTITIONS OF THE COLD STORAGE CHAMBERS
}

\author{
Chmielewski R., Kruszka L., Muzolf P. \\ Military University of Technology, Warsaw, Poland \\ Leopold.Kruszka@Wat.edu.Pl
}

Received by the Editor 2019/04/09

\begin{abstract}
The paper presents problems related to the load-bearing capacity analysis of the building partitions of the cold storage facility. The subject of the case study are two different buildings built in the early fifties of the last century. Despite the similar cubature and the construction period, the structures of these buildings are different. The analysed cold store in Warsaw (Poland) is a steel and brick structure, while the second example concerns a reinforced concrete slab-pillar structure located in Włocławek (Poland). In both cases, the issue related to the assessment of the current technical condition of the structural elements, including the safety of the load-bearing structure and the safety of its use was considered. Moreover, the permissible load for inter-storey slabs in both cases was determined. In order to properly determine the current load-bearing capacity of inter-story slabs, the archival technical and operational documentation of buildings was firstly analysed. Their technical condition was also taken into account in the assessment process. In-situ inspections of both buildings had been carried out. This allowed the determination of the scope of necessary tests and the selection of test and check points for each structural element. Such actions allowed to identify cross-sections of the structural elements and the parameters of built-in materials. The performed diagnostics also allowed to properly determine the technical condition of each structural element, the degree of degradation of the structure and to correctly determine its current load-bearing capacity while simultaneously satisfying both limit states - the Ultimate Limit State (ULS) and the Serviceability Limit State (SLS).
\end{abstract}

Keywords: load-bearing capacity, safety, building partitions, permissible load, diagnostics, technical condition, limit states.

\section{Introduction}

The determination of the load-bearing capacity of the structures of the existing buildings requires a special approach in assessing their technical condition, including the determination of the parameters of built-in materials [1,2]. These materials, if the design documentation is not available, should be assessed using experimental methods for testing their strength or other mechanical properties [3]. In case when the design and technical documentation is available, non-destructive testing and in-situ inspections or visions may be sufficient $[4,5]$. The results of measurements of the individual structural elements should be properly interpreted, taking into account their location, layering as well as the 
thickness. An example of such a misinterpretation is the assumption of the designer and the later use of a $9 \mathrm{~cm}$ thick concrete slab (a top layer) in the Ackerman ceiling in the building built in the 1940s [1]. In literature, this thickness is assumed to be $3 \mathrm{~cm}$ or $4 \mathrm{~cm}$. If it is necessary to increase the usable height of the cross-section, an additional perforated brick layer is being used on the hollow brick layer. The designer took that wrong dimension on the basis of the result of one inspection hole, which was drilled near the reinforced concrete stairs. As a result of the erroneous determination of the ceiling load-bearing capacity, together with the builder fault of the contractor, the ceiling structure was damaged. This also implied the need to verify the design and implemented solutions. Five additional testbore-holes of the Ackerman block ceiling layers were made, in which the thickness of the concrete overlayer was found to be less than $4 \mathrm{~cm}-$ Fig. 1 .

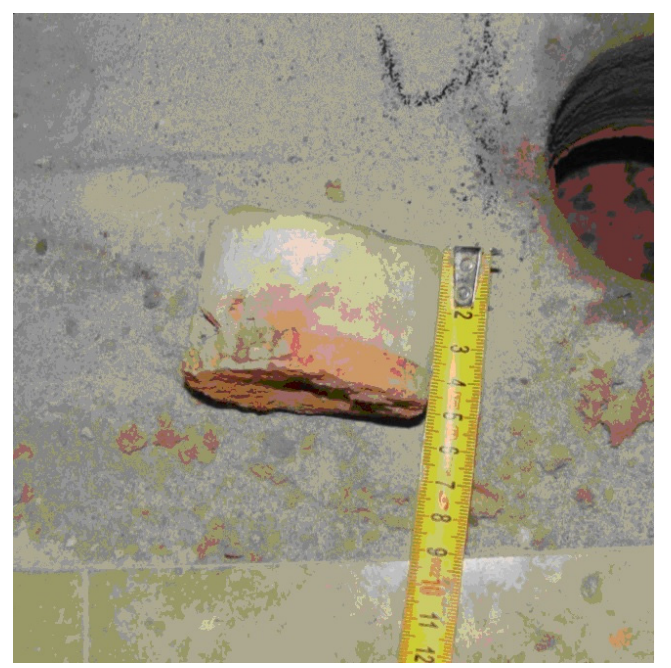

Fig. 1. Measurement of the thickness of the concrete slabthe overlayer of the Ackerman block ceiling

Another frequent error occurring during the verification process of the load-bearing capacity of existing structures is the failure of taking into account the actual thickness, and thus the loads of the non-structural layers. In the Ackerman ceiling case described above, one of the errors was the lack of removal of the screed layer, which the designer mistakenly treated as a structural layer. To make matters worse, an additional concrete floor of $6.5 \mathrm{~cm}$ was made, which resulted in an additional total ceiling load with a characteristic value of $1.63 \mathrm{kN} / \mathrm{m}^{2}$ [1]. Another case, which the authors met in their expert practice, concerned the failure to take into account the weight of the layers on the ceiling. In this case, the designer did not take into account $10 \mathrm{~cm}$ of insulating board made of wood chips and $6 \mathrm{~cm}$ of extra concrete layer, which gave the total characteristic load of $1.94 \mathrm{kN} / \mathrm{m}^{2}$ [1]. In both described cases, it was necessary to dismantle non-structural layers, including new finishing layers.

The abovementioned examples show that the suitable identification of the structure and the thicknesses of non-structural layers is crucial and a key issue in the design process as well as for the carrying out of the structure. An additional important step is the proper assessment of the degree of technical wear. 


\section{Description of the cold storage structure buildings}

1.1. Cold storage in Warsaw (Poland). The five-storey cold storage building in Warsaw is a masonry and steel structure with supporting pillars in the form of complex I260 double I-shaped beams with brick elements. The columns are supported by steel binders transmitting loads from the ceiling sections. The roof of the main cold storage is covered with reinforced concrete with a beam-and-slab floor structure. The surface area of the building is $4823 \mathrm{~m}^{2}$, and the total cubature of $52540 \mathrm{~m}^{3}$. The whole building structure is based on a monolithic foundation slab.

1.2. Cold storage in Włoclawek (Poland). Similarly to the building described above, the Włocławek cold storey was erected in the 1950s - Fig. 2. It is a fine-storey reinforced concrete building with a frame structure. The roof of the building is a slab-beam structure. Its columns with a cross-section of $0.2 \times 0.2 \mathrm{~m}$ (partially $0.25 \times 0.25 \mathrm{~m}$ ) are articulated on the heads of the columns of the third floor. Cross-sections of reinforced concrete columns of the supporting structure vary on individual floors:

$-3^{\text {rd }}$ floor: columns with a $0.4 \times 0.4 \mathrm{~m}$ section in the cold storage chambers (freezers), $0.3 \times 0.45 \mathrm{~m}$ in the tunnel freezer and $0.35 \times 0.45 \mathrm{~m}$ in the loading dock;

$-2^{\text {nd }}$ floor: columns with a cross-section of $0.5 \times 0.5 \mathrm{~m}$ in the cold storage chambers (freezers), $0.3 \times 0.45 \mathrm{~m}$ in the tunnel freezer block and $0.4 \times 0.45 \mathrm{~m}$ and $0.4 \times 0.5 \mathrm{~m}$ in the loading dock;

$-1^{\text {st }}$ floor: columns with a $0.6 \times 0.6 \mathrm{~m}$ section in the cold storage chambers (freezers), $0.4 \times 0.65 \mathrm{~m}$ in the loading dock;

- ground floor: columns with a section $0.7 \times 0.7 \mathrm{~m}$ in the cold storage chambers (freezers), $0.4 \times 0.65 \mathrm{~m}$ and $0.5 \times 0.8 \mathrm{~m}$ in the loading dock;

- cellars: columns with a section $0.8 \times 0.8 \mathrm{~m}$ in the freezer chambers, $0.55 \times 0.8 \mathrm{~m}$ and $0.6 \times 0.8 \mathrm{~m}$ in the loading dock.

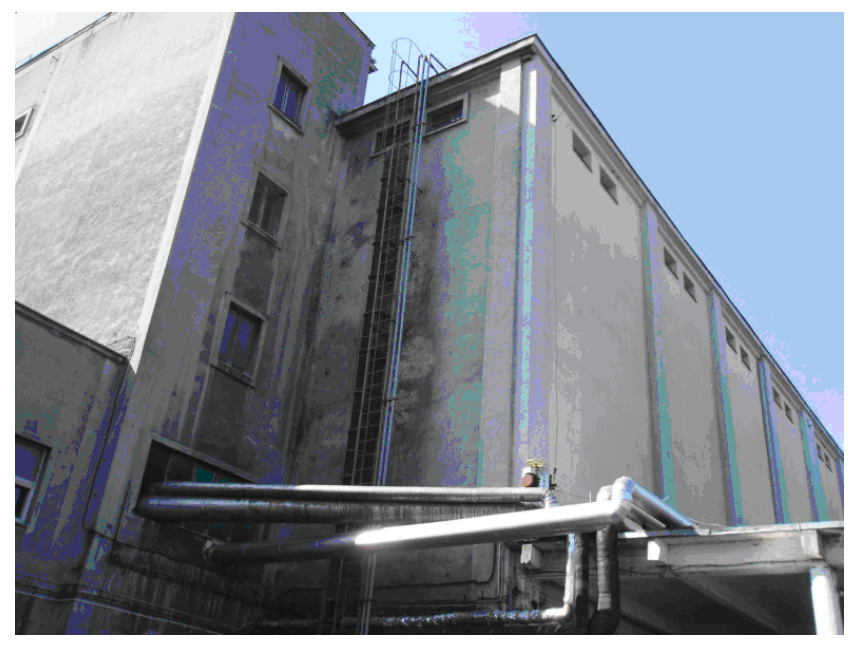

Fig. 2. General view of the cold store in Włocławek

\section{Determination of the load-bearing capacity of building structures}

2.1. Cold storage in Warsaw (Poland). The structural elements which determined the load-bearing capacity of the cold store building in Warsaw erected before II WW, were 
the inter-story slabs and columns at the ground floor level - Fig. 3. In the first place, the loads and self-weight acting on the ceiling were calculated. The actual thicknesses of the ceilings and finishing layers was taken into account, which were verified in the performed in-situ inspection holes. The determined design value of the pressure applied on the floor layers was $8.29 \mathrm{kN} / \mathrm{m}^{2}$. On the basis of abovementioned inspection holes, it was found that the spacing of the steel beams was $1.34 \mathrm{~m}$, while the maximum span was $l_{0}=4.8 \mathrm{~m}-$ Fig. 4. The supporting elements of the ceiling were I240 rolled I-beams.

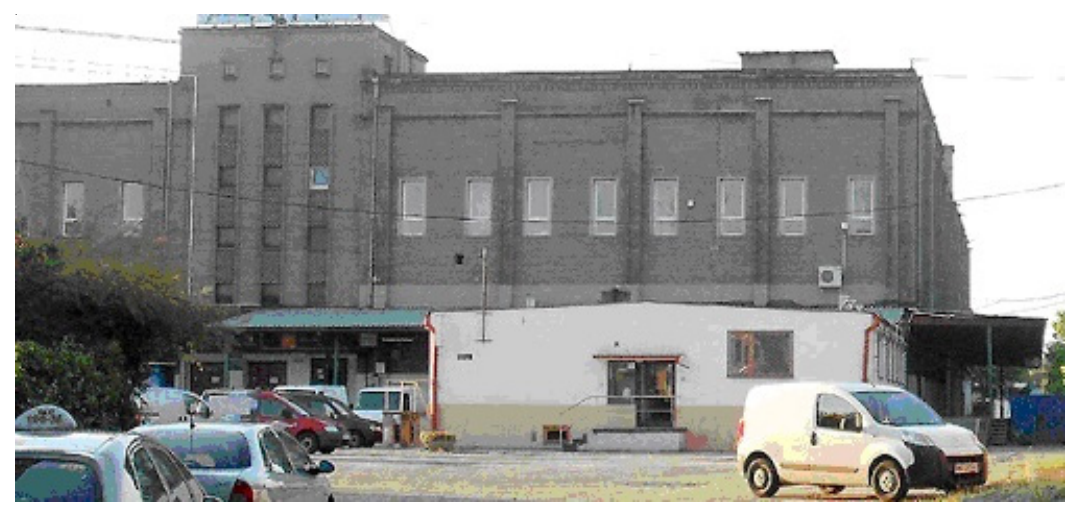

Fig. 3. General view of the cold store in Warsaw

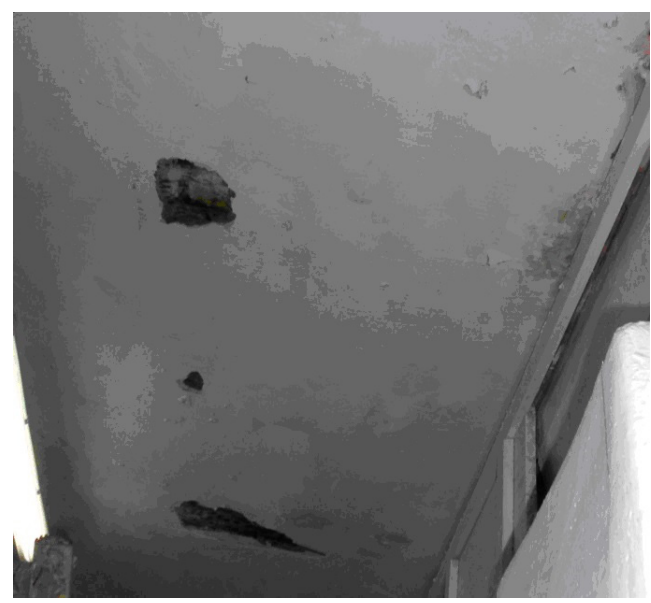

Fig. 4. "In-situ" inspection hole of Klein ceiling beams in the cold store in Warsaw

The strength parameters of A- 0 grade steels were adopted for static and strength calculations. The strength parameters of the girder were then selected based on the design tables and the actual degree of corrosion for each structral element. Moreover, the girder slenderness as well as the plastic reserve factor were taken into account in the verification calculations. Moreover, the girder slenderness as well as the plastic reserve factor were taken into account in the verification calculations. The load-bearing capacity of the ceiling beams was determined. Then the load capacity loss was calculated due to the self-weight of the structure elements. The load capacity reserve allowed to determine the permissible characteristic loads due to the load-bearing capacity of the steel ceiling girders.

The next checked element, which could decide on the permissible loads for the whole structure, were the steel columns. First, the ceiling area was determined for each of the 
pillars and the permanent load as well as the climatic loads (bags of snow on the roof) were collected. The operational load in the attic as well as the equivalent static load from partition walls on all floors were also taken into account to calculate the remaining loads acting on each column. The columns made of two I260 rolled I-sections with a $12 \mathrm{~cm}$ spacing are shown in Fig. 5.

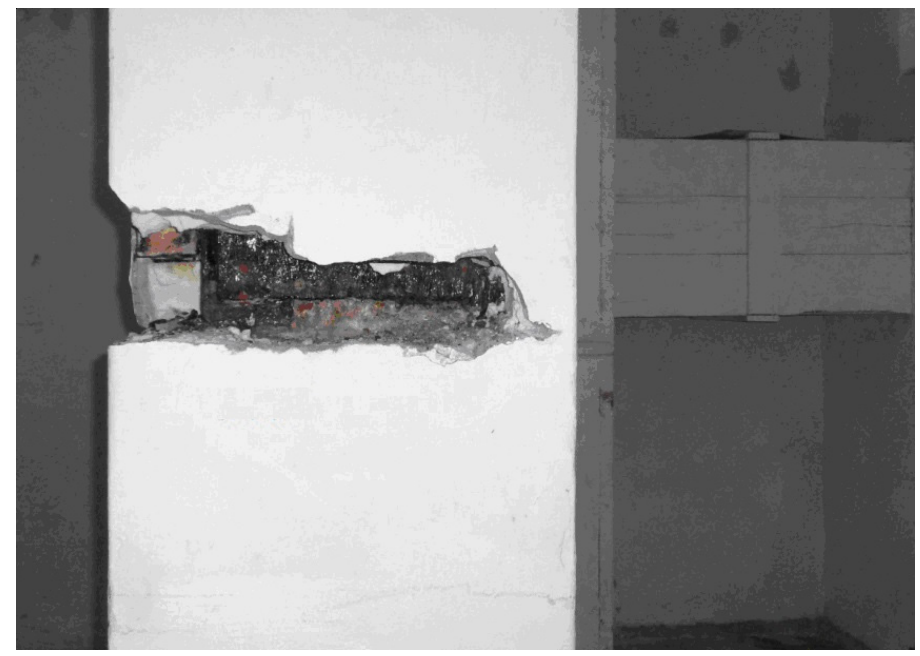

Fig. 5. "In-situ" inspection hole of the steel supporting structure of the column. Visible degree of column corrosion

The basement level was assumed to be the most representative for the calculations, in which the columns transfer the loads from all floors of the building. When determining the permanent load, the weight of the ceiling structures on particular floors, the weight of the roof, the weight of the columns, as well as the weight of the binders were taken into account. As in the case of the steel girders, the load capacity of the columns was determined taking into account their slenderness and the buckling coefficient. The calculated load capacity of the columns allowed to determine the permissible value of the design operational load.

The Klein ceiling beams proved to be the most decisive factor in the load-bearing capacity. The permissible value of the characteristic operational load for the cooling tower ceiling in Warsaw was $7.5 \mathrm{kN} / \mathrm{m}^{2}$. In the next step the Ultimate Limit State was being checked.

2.2. Cold storage in Włoclawek (Poland). With regard to the cold store building in Włoclawek, the key element for the load-bearing capacity of the structure were the floor slabs, made as monolithic reinforced concrete. The thickness of the reinforced concrete slab was $22 \mathrm{~cm}$ and the maximum span width was $6.10 \mathrm{~m}$. During the carrying out of the inspection hole of the ceiling, it was found that the main reinforcement of the ceiling consisted of the alternated bars with a square cross-section of $12 \mathrm{~mm}$ and round bars $\varnothing 14 \mathrm{~mm}$ at a spacing of $10 \mathrm{~cm}-$ Fig. 6 .

The main bars with a square cross-section of $12 \mathrm{~mm}$ were orthogonally ribbed and made of St50B steel. The yield strength of this steel is $360 \mathrm{MPa}$. Assembly bars, perpendicular to the main reinforcement, occurred every $30 \mathrm{~cm}$. Their cross-section was square $12 \times 12 \mathrm{~mm}$. The lagging of the main steel reinforcement and assembly bars was $20 \mathrm{~mm}$ and $40 \mathrm{~mm}$, respectively. On the basis of visual assessment and sclerometer tests, the concrete parameters corresponding to class C25/30 (B25) and parameters of A-II class 
steel $[1,6,7]$ were assumed for the calculations. The total ceiling thickness was $47 \mathrm{~cm}$. Analysing the layering system from the top, an $8 \mathrm{~cm}$ layer of screed reinforced with steel mesh was found. Then, a $17 \mathrm{~cm}$ frost-resistant layer in the form of a cork and a $22 \mathrm{~cm}$ reinforced concrete slab were observed. The geometric parameters of the ceiling crosssection, that were adopted for calculations are, shown in Fig. 7.

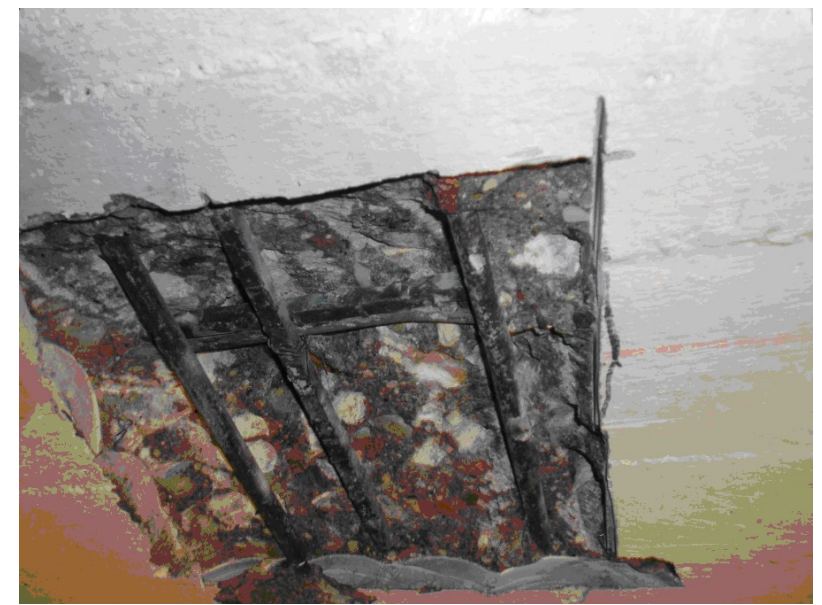

Fig. 6. Inspection hole of the ceiling of the cold storage building in Włocławek

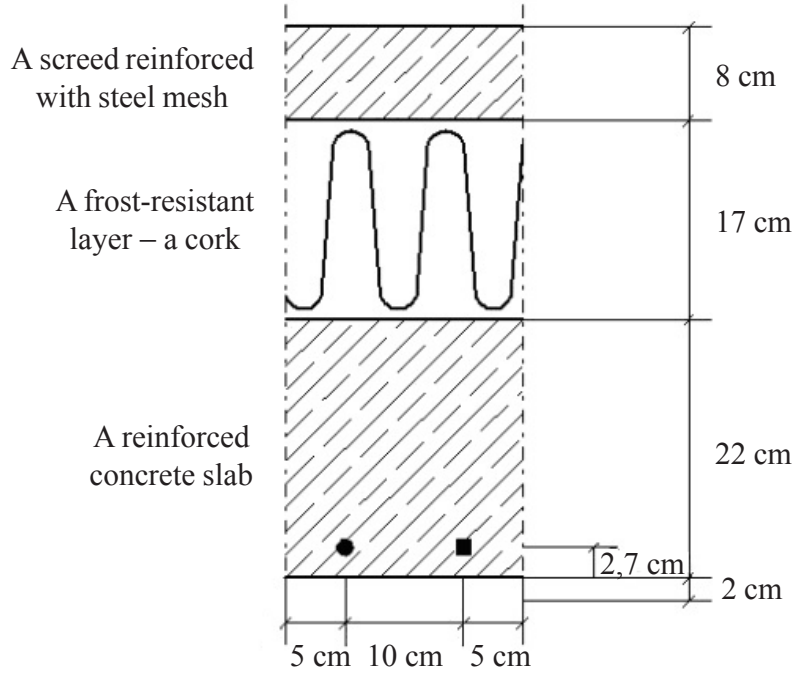

Fig. 7. The cross-section of the reinforced concrete ceiling section of the cold storage building in Włocławek

On the basis of the strength parameters of concrete and steel, the effective height of the concrete compression zone was determined and the design load-bearing capacity of the ceiling section was calculated. The static scheme of the ceiling section was assumed as a multi-span continuous beam based on binders. As in the case of the cold store ceiling in Warsaw, the ceiling load-bearing capacity was determined in a first place. Both, the actual weight of the structural and non-structural layers of the ceiling were considered. This capacity reserve allowed to determine the permissible value of design operational 
loads. After considering the technical condition and ceiling wear, its operational load was specified as $8.8 \mathrm{kN} / \mathrm{m}^{2}$.

\section{Discussion}

The analysed buildings were built in the same period of time and according to the same regulations and technical standards binding at that time. Despite the very similar dimensions of the cold storage buildings and similar spans of structural elements, they were made of various construction materials. However, the use of various built-in construction materials, in combination with the real estate maintenance process and conditions, caused a different degree of technical wear of these cold storage facilities. The masonry and steel structure built in Warsaw was much more damaged than the reinforced concrete structure of the cold storage in Włoclawek. Weather conditions and the environment, including low temperatures combined with the moistness of the structural elements caused significant corrosion of steel elements. The loss of the cross-sectional area of the steel structural elements caused by corrosion amounted to approximately $0.5 \mathrm{~mm}$. It caused the weakening of the cross-sections by $10 \%$ (reduction of the strength index). The technical wear in the reinforced concrete structure was much lower. The degree of corrosion of the reinforcement and concrete was much smaller and the determined weakness of the sections of the structural element was 3\%. The factor that caused the most technical wear and weakness of the struc-tural elements was moisture. The improperly thermally insulated walls and ceilings of the cold storage chambers were subjected to moisture and the accelerated degradation - Fig. 8.
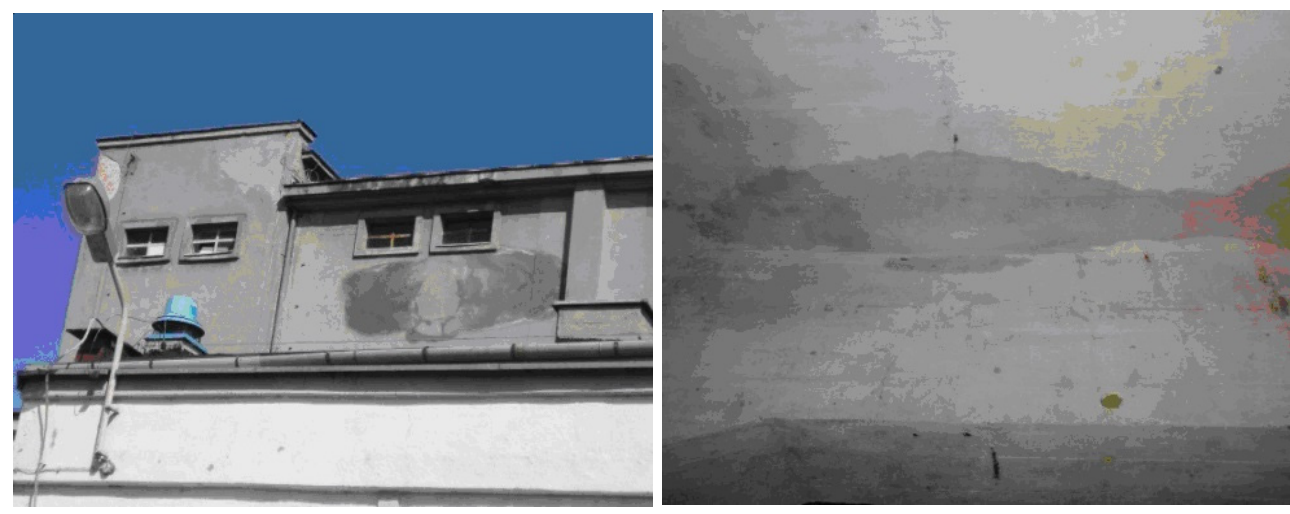

Fig. 8. The examples of the moisture-caused damages of the cold storage structural elements

Moisture in the structural elements had a particularly destructive effect on the steel elements that were unprotected against corrosion. The actual thickness of the ceiling layers was verified in the performed in-situ inspection holes. This enabled then a precise determination and assessment of the technical condition of each structural element of the ceiling. The renewal of the frost-resistant layers was recommended in both presented cases. The disassembly of the floor layers in cold storage rooms required special attention to the manner of conducting the construction works. The use of a manual and a light equipment was allowed due to the possibility of the disturbance in the behaviour of the ceiling structure.

The difficulties associated with the need to remove the non-structural layers, especially the levelling screeds, usually cause the builders to leave them on site. This results both 
from the need to perform difficult manual demolition works and from the fear of damaging the floor slab structure, especially in the case of ribbed floor slabs.

\section{Conclusions}

In order to correctly determine the value of operational loads in the existing structural objects, it is necessary to diagnose the technical condition of structural elements and also to examine the actual loads from the weight of non-structural layers. In particular, this analysis should be based on "in-situ" measurements of the structural elements and on the investigation of their material characteristics. In the case of assessing the load-bearing capacity of the existing structure, the design and the as-built documentation can only provide guidance on the material or the engineering solutions applied [8]. Even despite the statement of a construction manager about the compliance of the construction according to the project documentation, it often turns out that there are discrepancies between the documentation and the reality $[3,6]$.

The calculation models used to verify or to determine the load-bearing capacity of the entire structure and its individual components should have included these risks. The model should have considered the boundary conditions, including the stiffness of the joints as well as the effective lengths and spans of the elements $[9,10]$.

The presented scope of the analysis of the current load-bearing capacity in the cold storage buildings can be used as a representative example in similar cases. This particularly applies to the diagnostics and the assessment of the technical condition of the structure and the determination of its actual weight of non-structural layers. When examining an existing structure, it is necessary to apply calculation models that should accurately reflect the actual behaviour of the structure $[9,10]$. In addition, the mode of building operation and the possibility of local overloading should be taken into account, which was crucial in the analysed cases of the cold storage chambers.

Every civil engineering structure should ensure safety during its use. In order for this condition to be met, the appropriate dimensions of the building and the materials used for its construction must be determined at the design stage. A detailed investigation and study of the material and geometric characteristics of the structural elements enables the safe transferring of applied loads, while satisfying two principal criteria - the ultimate limit state (ULS) and the serviceability limit state (SLS). The load-bearing capacity of a structural object can be significantly different from the one assumed in the design documentation, hence an important element is the performance of diagnostics that will safely assess the actual parameters of the structure. The analysis stage, which is often omitted, is the determination of the time of safe operation of the structure. This is particularly important for the facilities that have been in operation for a long period of time, often for over 50 years. It should be taken into account that with the passage of time, the degradation of the structure does not increase linearly but geometrically.

\section{References}

1. Chmielewski R., Kruszka L. Expertises and technical opinions in the area of building construction. Wojskowa Akademia Techniczna. Warsaw. 2005-2017 (In Polish).

2. Drobiec L., Jasiński R., Piekarczyk A. Diagnostics of Reinforced Concrete Structures. Methodology, Field Tests, Laboratory Tests of Concrete and Steel 1. Warsaw. 2010 (In Polish).

3. Hola J., Schabowicz K. State-of-the-art non-destructive methods for diagnostic testing of building structures - anticipated development trends. Archives of Civil and Mechanical Engineering. 2010. Vol. 10. Iss. 3. P. 5-18. 
4. Adnan N.A. Assessment the strength of column and beam at religious building structure by using non-destructive test. MATEC Web of Conf.: International Symposium on Civil and Environmental Engineering 2016. 2017. Vol. 103. P. 1-10.

5. Ilharcoa T., Lechnerbc T., Nowak T. Assessment of timber floors by means of non-destructive testing methods. Construction and Building Materials. 2015. Vol. 101. Pt. 2. P. 1206-1214.

6. Zybura A., Jaśniok M., Jaśniok T. Diagnostics of Reinforced Concrete Structures. Corrosion Tests of Reinforcement and Concrete Protective Properties. Warsaw. PWN Publ. 2010 (In Polish).

7. Zybura A., Jaśniok M., Jaśniok T. Evaluation of the danger of corrosion of the reinforcement of reinforced concrete structures. Pt. 1 - testing of the protective properties of concrete. Przeglad Budowlany. 2012. Vol. 11. P. 29-35 (In Polish).

8. Kruszka L. Reinforcement of brick historic buildings threatened by structural damages or by failure. MATEC Web of Conf:: $3^{\text {rd }}$ Scientific Conference Environmental Challenges in Civil Engineering. 2018. Vol. 174. P. 1-11.

9. Murzewski J. Reliability of Engineering Structures. Warsaw. Arkady. 2001 (In Polish).

10. Terenchuk S., Yeremenko B., Sorotuyk T. Implementation of intelligent information technology for the assessment of technical condition of building structures in the process of diagnosis. Eastern-European Journal of Enterprise Technologies. 2016. Vol. 5. No 3. P. 30-39.

\section{АНАЛИЗ НЕСУЩЕЙ СПОСОБНОСТИ СТРОИТЕЛЬНЫХ КОНСТРУКЦИЙ ХОЛОДИЛЬНЫХ КАМЕР}

Хмелевский Р., Крушка Л., Музолф П.

Военный технологический университет, Варшава, Польша

Представлены проблемы, связанные с анализом несущей способности элементов конструкций холодильного хранилища. Предметом тематического исследования являются два разных здания, построенных в начале пятидесятых годов прошлого века. Несмотря на одинаковую кубатуру и период строительства, конструкции этих зданий различны. Анализируемое холодильное хранилище в Варшаве (Польша) представляет собой стальную и кирпичную конструкцию, а второй пример касается железобетонных плит башни, расположенной в Влоцлавеке (Польша). В обоих случаях был рассмотрен вопрос, связанный с оценкой текущего технического состояния конструктивных элементов, включая безопасность несущей конструкции и безопасность ее использования, была определена допустимая нагрузка на межэтажные плиты. Чтобы правильно определить текущую несущую способность межэтажных плит, был проанализирован архив технической и эксплуатационной документации зданий. Их техническое состояние было также учтено в процессе оценки. На месте были проведены инспекции обоих зданий. Это позволило определить объем необходимых испытаний и выбрать контрольные точки для каждого элемента конструкции, выявить сечения элементов конструкции и параметры встроенных материалов. Проведенная диагностика позволила надлежащим образом определить техническое состояние каждого элемента конструкции, степень деградации конструкции и правильно определить ее текущую несущую способность при одновременном удовлетворении обоих предельных состояний.

Ключевые слова: несущая способность, безопасность, конструктивные элементы, допустимая нагрузка, диагностика, техническое состояние, предельное состояние. 